\title{
HOW THE NEWS MEDIA SE'T THE AGENDA
}

\author{
MaXwell McCombs*, Iris Chyi**, SPIro KiOUSis*** \\ *holds the Jesse H. Jones Centennial Chair in Communication at the University of Texas at Austin; \\ ${ }^{*}$ ASSISTANT PROFESSOR AT THE CHINESE UNIVERSITY OF HONG KONG; \\ ${ }^{* * *}$ ASSISTANT PROFESSOR AT THE UNIVERSITY OF FLORIDA
}

\section{Resumen}

El papel de "agenda-setting" (fiijación de la agenda) desempeñado por los medios informativos condiciona en gran medida no solamente el abanico de cosas que nos llaman la atención, sino también nuestra manera de entender el mundo ingente de asuntos públicos que existe más allá de nuestra experiencia personal. El Chapel Hill Study de 1972 marcó un antes y un después en el desarrollo de la teoría de agenda setting. Hasta este momento clave se había limitado a la influencia que ejercen los medios informativos sobre el público; a partir de este trascendente estudio la teoría abrió sus horizontes y empezó a abordar el proceso más amplio de agenda setting. La gama de asuntos abarcado por la teoría hoy en día va desde los condicionantes de la agenda mediática hasta los efectos de agenda-setting sobre las actitudes y opiniones. En este trabajo se presentan los resultados de dos estudios empíricos publicados recientemente en los EEUU. Estos dos estudios elaboran aún más este proceso. El primero explica cómo la prensa cambia el foco de su atención dentro de un acontecimiento informativo importante, iluminando primero un aspecto y luego otros para así establecer la prominencia de dicho acontecimiento en la agenda mediática. El segundo explica el efecto que ejerce la prominencia en la agenda mediática sobre la actitud del público y las opiniones que se tienen de las personalidades públicas.

\section{Abstract}

The agenda-setting role of the news media is a powerful influence on what we pay attention to and how we understand the vast world of public affairs that lies beyond our personal experience. Subsequent to the seminal Chapel Hill study in 1972, agenda setting theory has expanded beyond the influence of the news media on the public to elaborate the broader process of agenda setting. The scope of the theory now extends from the elements that shape the media agenda to the consequences of agenda-setting effects for attitudes and opinions. This article presents the results of two empirical studies recently published in the United States that further elaborate this process. One explicates how the press shifts its spotlight from one aspect to another of a major news event to build the prominence of that event on the media agenda. The second explicates the implications of prominence on the media agenda for the public's attitudes and opinions about public figures. 
The agenda-setting role of the news media is a powerful influence on what we pay attention to and how we understand the vast world of public affairs that lies beyond our personal experience. Here we present two recently published studies on this agenda-setting process:

how the press shifts its spotlight from one aspect to another of a major news event to build the prominence of that event;

the implications of prominence on the media agenda for attitudes and opinions about public figures.

Since the seminal Chapel Hill study during the 1968 US presidential election, the process of agenda setting has been analyzed in election and non-election settings worldwide for a broad variety of public issues and recently for numerous other agenda items, such as political candidates and public figures. This vast empirical literature, now numbering in the hundreds of publications, has expanded agenda-setting theory far beyond its original domain, the influence that the prominence of an issue, person or other object on the media agenda has on the prominence and perceived importance of that object on the public agenda. There are now four other theoretical domains:

the contingent conditions that mediate the strength of this agenda-setting influence of the media on the public;

the origins of the media agenda;

a second level of agenda setting concerned with how we comprehend these objects, which is grounded in the prominence of the attributes of issues or other objects on the agenda, a domain usually referred to as attribute agenda setting;

the consequences of agenda setting effects, both traditional agenda setting and attribute agenda setting, for attitudes and opinions and for behavior.

Here we present two new studies that expand our knowledge in the latter two domains, how the media frame the attributes of news events and the consequences of agenda setting for opinions about public figures.

\section{BUILDING PUBLIC ATTENTION}

An underlying assumption of agenda-setting theory is that once an object appears on the media agenda, the volume of cumulative news coverage increases its prominence and perceived importance among the public. However, the process by which the news media build up the prominence of a topic on the media agenda has received little attention. A forthcoming study in Journalism \& Mass Communication Quarterly by Chyi and McCombs examined how the media build a news event's prominence over time - a dynamic process called frame-changing in which the news media 
re-frame an event by emphasizing different attributes of the event in order to keep the story alive and fresh.'

To facilitate the empirical examination of this journalistic practice of frame-changing, Chyi and McCombs proposed a two-dimensional model as a systematic approach to the study of framing for any object in the news. The model is grounded in two dimensions: time and space. Inherent in the definition of news, "space" and "time" are two of the most important dimensions pertinent to the coverage of any news events. These two dimensions represent central organizing ideas in journalistic practice.

The first dimension -space- consists of five levels: individual, community, regional, societal, and international. For example, at the individual level, a news event is framed within a scope that is limited to the individuals involved in an event; e.g., a crime story featuring the particulars about the perpetrator or the victim. At the international level, a news event is framed from an international perspective; e.g., military action in a foreign country analyzed in terms of power relationships among different countries.

The second dimension is time. Although conventional wisdom is that news deals with present happenings, news stories may focus on the past - providing historical backgrounds or tracing related events in the past -or the future- making predictions about further developments, proposing actions to be taken, or evaluating the impact of the event in the future.

Combining these two dimensions, this model, which is illustrated in Figure 1, sorts frames by space and time. In the past, framing research has been characterized by

Figure 1: The Two-Dimensional Measurement Scheme

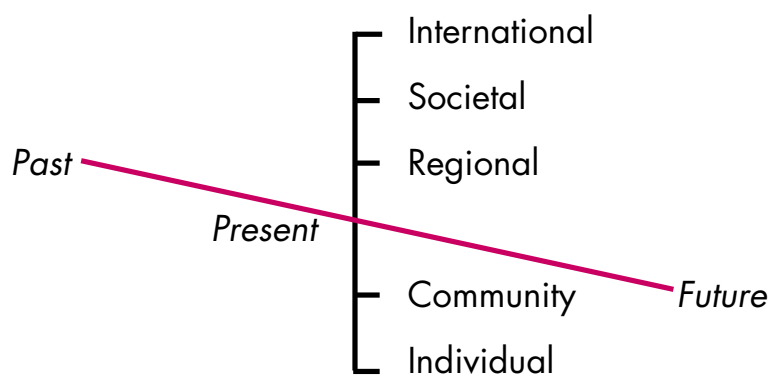

the lack of continuity, as the attributes of one object usually are not generalizable to other objects. With minimal constraints on specific substantive content while simultaneously capturing major 
aspects of the news, this model yields cross-issue generalizability that liberates framing research from issue-specific boundaries. It also provides an exhaustive and mutually exclusive list of frames on the time and space dimensions that is applicable for any news event or object in the news.

\section{APPLYING THE MODEL}

For the initial test of this model, Chyi and McCombs content analyzed the coverage of a specific news event in the New York Times and identified the specific attributes of the event that contributed to its prominence on the media agenda. The news event selected for analysis was the Columbine school shootings in the United States. On April 20, 1999, two young gunmen in Littleton, Colorado, killed twelve fellow students and a teacher before turning their guns on themselves - the worst school shooting in U.S. history. A total of 170 news stories and editorials articles related to the Columbine school shootings published in the New York Times between April 21, 1999 and May 20, 1999 were content analyzed.

These articles, which adopted various frames on the space and time dimensions, successfully kept the Columbine story alive in the newspaper for 30 days (and beyond) and contributed to its prominence on the media agenda. The coverage reached its peak on April 22 - immediately after the incident first appeared in the news, but continuing coverage kept this news event on the media agenda throughout the month.

On the space dimension, the frames were distributed across all five levels ranging from individual to international, indicating substantial frame-changing. The three most prominent frames were societal $(52 \%)$, community $(29 \%)$, and individual $(17 \%)$. With the societal frame dominating, the school shootings were mostly discussed in the larger social context where issues such as gun control received major attention.

Over time, these societal frames steadily increased - from 38 percent to 78 percent during the first twenty-five days. Conversely, the percentage of individual frames decreased - continuously dropping from 30 percent to zero. This frame-changing pattern reflects a shift in focus from the specific to the general - from reports on personal details to discussion of violence as a social problem.

On the time dimension, the vast majority of the coverage, 71 percent, adopted the present frame. Only 16 percent of the stories dealt with the past and 13 percent focused on the future. Throughout the one-month period analyzed, use of the present frame was consistently high - over 50 percent on most days, while the use of the past and future frames complemented each other. The future frame became more prominent over time while the past frame gradually faded out. In this frame-changing pattern, reports of historical background were replaced by discussion about preventive measures.

Looking at the relationship between the use of space frames and the use of time frames, the "societal and present" combination (39 percent) dominated the framing of this particular news 
event, while only 24 percent of the stories were framed at the community level with a focus on current developments. Over time, the news coverage moved substantially beyond the specific news event as both the societal frame and the future frame gained ground.

Objects on the news are likely to have a core framing - defined as the framing that initially propelled the object into the news. However, that core framing is likely to be complemented by a changing pattern of extended frames over time. In the Columbine case, the combination of "community" and "present" on the space and time dimensions, respectively, constitute the "core" frame because the "community and present" combination is the most pertinent to the nature of the school shootings. All the other combinations then constitute "extended" frames. With only 24 percent of the Columbine stories adopting the core frame, the vast majority of the coverage was actually grounded in extended frames. It is these extended frames (especially the societal frame) that are the major component of this event's prominence and importance on the media agenda.

This use of extended frames needs further exploration. How is it related to an event's prominence on the media agenda? And, most importantly, to its subsequent perceived importance among the public? Mapping these narrative strategies of journalism and their impact on the public is an important goal for continuing research that will enhance our understanding of journalism and its agenda-setting role.

\section{AGENDA-SETTING EFFECTS AND OPINIONS}

In contrast to the ubiquity of empirical work that has concentrated on how media agenda-setting influences people's cognitions, namely, the prominence of various issues, persons and other objects in their mental pictures of the world, a small research stream recently has emerged exploring its attitudinal consequences and connecting the theory of agenda-setting to the affective domain of public opinion. For example, research on priming has shown that the issues emphasized in the news become the issues used by voters to evaluate political candidates. In addition to priming, other research has found an empirical relationship between agenda-setting effects and the strength of people's attitudes and opinions. However, our theoretical map of this domain remains sketchy. To remedy this situation, Kiousis and McCombs created a theoretical model of how media agenda setting affects attitude strength. Drawing upon the idea of a hierarchy of effects, this general model suggests that communication and persuasion occurs through a sequence of steps where message exposure leads to changes in cognition, affect, and behavior (CAB) among the public.

In a study recently published in Communication Research, Kiousis and McCombs tested this model with a series of extensive comparisons of news coverage and public opinion about public figures during the 1996 presidential election ${ }^{2}$. The news coverage was examined in seven national network television news broadcasts, newspapers, and news magazines. The specific news outlets were ABC News, CBS News, The New York Times, Los Angeles Times, Washington Post, Newsweek, and U.S. News \& World Report. Stories were gathered through keyword searches in the LexisNexis database from June through October, 1996, ending prior to the election in early November. 
The 11 specific public figures were Hillary Clinton, Pat Buchanan, Jesse Jackson, Newt Gingrich, Colin Powell, Steve Forbes, Phil Gramm, Louis Farrakhan, Lamar Alexander, Elizabeth Dole, and Pat Robertson - a wide range of public figures on the U.S. political landscape.

Public opinion data were obtained from the University of Michigan's pre-election poll. The primary items used to gauge public opinion were feeling thermometers for these various political figures. These feeling thermometers, which asked respondents to rate figures on a 100-point scale, with 100 representing strong positive feelings and 1 representing strong negative feelings, were used to construct scales measuring perceived, prominence, attitude dispersion, and attitude polarization.

Perceived prominence was defined as name recognition. The percentage of respondents who did not recognize a political figure was subtracted from 100 percent to create the prominence measure. Attitude dispersion was defined as the percentage of respondents who held non-neutral opinions about the public figures (i.e., anywhere on the 100-point scale except the 50-point mark). Attitude polarization was defined as the percentage of respondents who held extreme opinions about the public figures (i.e., at the 1 and 100-point ends of the scale).

To measure the relationship between prominence on the media agenda and these three attitude outcomes, the variations in the amount of media coverage for these 11 public figures was compared to the variations in the public's opinions about them. This comparison of the range of media coverage with the range of opinions for this set of 11 persons was done separately for each of the seven news media.

\section{MEDIA COVERAGE AND OPINIONS}

Consistent with traditional agenda-setting research on issue salience - the prominence of an issue in the media and the perceived importance of the issue among the public - as the prominence of these public figures increased in the news, the proportion of people who recognized them also increased. For each of the seven news media, the pattern of coverage for these public figures was compared with the pattern of recognition among the public, and the median correlation was a robust +.58 . In other words, the ranking of these 11 individuals according to how much news coverage each received is significantly related to their ranking according to how many people recognized them.

When each of these seven patterns of news coverage was compared with measures of attitude strength among the public, the median correlation was +.81 for opinion dispersion and +.70 for opinion polarization. In short, variations in media attention to these public figures are not only linked to the extent of their name recognition, but also to the strength of the public's opinions about them as well.

Kiousis and McCombs next turned to examining two competing models regarding the sequence of outcomes: prominence in the media prominence among the public attitude strength 
VERSUS prominence in the media attitude strength prominence among the public. Strong evidence was found that attitude dispersion intervened between media and public prominence. Six of the seven analyses supported this sequence of outcomes. For the other measure of attitude strength, attitude polarization, the evidence was mixed. None of the evidence supported the alternative sequence, prominence in the media prominence among the public attitude strength.

In short, a significant relationship appears to exist between agenda-setting and attitude strength, particularly attitude dispersion. Researchers should not just scrutinize how the transfer of salience occurs in agenda-setting, but also more attention should be paid to its outcomes and how it connects to broader communication processes.

Journalism plays a major role in the workings of democracy, influencing which issues, persons and objects that we pay attention to, how we think about these objects, and how we feel about these objects. Just as the spotlight of the press influences the functioning of democracy, the spotlight of rigorous scholarship expands our explicit understanding of this agenda-setting role of the press.

\section{REFERENCES}

- Chyi, I., McCombs, M., "Media Salience and the Process of Frame-Switching: Coverage of the Columbine School Shootings, Journalism \& Mass Communication Quarterly (in press).

- Kiousis, S., McCombs, M., "Agenda-Setting Effects and Attitude Strength: Political Figures During the 1996 Presidential Election", Communication Research, 31 (February 2004) 36-57. 